University of Nebraska - Lincoln

DigitalCommons@University of Nebraska - Lincoln

2004

\title{
Great Plains Ecosystems: Past, Present, and Future
}

Fred B. Samson

United States Forest Service

Fritz L. Knopf

United States Geological Survey Biological Resources Division

Wayne Ostlie

The Nature Conservancy, wostlie@mnland.org

Follow this and additional works at: https://digitalcommons.unl.edu/usgsstaffpub

Part of the Earth Sciences Commons

Samson, Fred B.; Knopf, Fritz L.; and Ostlie, Wayne, "Great Plains Ecosystems: Past, Present, and Future" (2004). USGS Staff -- Published Research. 45.

https://digitalcommons.unl.edu/usgsstaffpub/45

This Article is brought to you for free and open access by the US Geological Survey at DigitalCommons@University of Nebraska - Lincoln. It has been accepted for inclusion in USGS Staff -- Published Research by an authorized administrator of DigitalCommons@University of Nebraska - Lincoln. 


\section{Great Plains ecosystems: ast, present, and future by Fred B. Samson, Fritz L. Knopf, and Wayne R. Ostlie}

Abstract Little question exists that the main bodies of North American prairie (i.e., the tallgrass, mixed, and shortgrass) are among the most endangered resources on the continent. The purpose of this paper is to provide a past and present biological baseline by which to understand North American prairies and to provide a platform for future conservation. Events both immediate to the end of the Pleistocene and historic suggest that the present grassland conditions are different from those within which most of the grassland organisms evolved. Our analysis suggests that few grassland landscapes remain adequate in area and distribution to sustain diversity sufficient to include biota and ecological drivers native to the landscape. A robust and history-based scenario to conserve Great Plains grasslands is to 1) identify areas large enough to sustain an ecological system with all its biodiversity, 2) reverse significant losses in area of native grasslands, 3 ) ensure that restoration matches the grassland previously existing at that site, 4) refocus the profession of range management, and 5) establish a more meaningful agency design for grassland and natural resource management.

Key Words biological diversity, conservation planning, ecological drivers, grasslands, management, prairie, restoration

ittle question exists that the main bodies of North American prairie (i.e., the tallgrass, mixed, and shortgrass) are among the continent's most endangered, and tallgrass is a globally endangered resource (Rickletts et al. 1999). Loss of North American prairie has had a profound and negative effect on native prairie plants and animals (Samson and Knopf 1994, 1996 and others).

Society can protect portions of endangered ecosystems in non-use preserves, but in the long run, partnerships among agencies, nongovernmental organizations, and private landowners will play a major role in the conservation of native biota and ecosystems (Raven 1990).

Although a framework for conservation is developing for the Great Plains (Risser 1996), major hurdles remain to understanding and integrating the variety of social, economic, and biological issues into efficient prairie conservation. In this paper we offer a platform for conservation built on principles that 1) prairie conservation must be based on an understanding of history, 2) conservation priorities must be based on more sophisticated (especially geospatial) information, 3) environmental legislation without ecological understanding may do more harm than good, and 4) just as natural resources are lost through ecosystem dysfunction, so are capabilities to support resource conservation lost without professional organization and natural-resource agency change.

Address for Fred B. Samson: United States Forest Service, 200 East Broadway, Missoula, MT 59812, USA; e-mail: FSamson@fs.fed.us. Address for Fritz L. Knopf: United States Geological Survey Biological Resources Division, 2150-C Center Avenue, Fort Collins, CO 80525, USA. Address for Wayne R. Ostlie: The Nature Conservancy, 4245 North Fairfax Drive, Suite 100, Arlington, VA 22203, USA. 


\section{Great Plains ecosystems - Samson et al.}

\section{Prairies through time}

\section{Prairie losses}

A comparison of the prairies of the past with those of the present provides a measure of 1) the loss or change in the extent of dominant ecosystems, 2) information on whether the frequency and extent of major ecological drivers (herbivory and fire) have changed, 3) an indication of the presence and impact of disturbances (humanrelated actions), and 4) a basis to develop conservation strategies to maintain or restore ecosystems, communities, species, and the ecological processes that maintain systems and habitat for species conservation (Haufler at el. 2002).

Flannery (2001:348) wrote that the time has come "to summarize what we have learned of the (evolutionary/ecological) forces shaping this New World and to look towards the great issues and dilemmas that North America will face in coming centuries." Flannery further suggests it may be worth considering the reintroduction of North American megafauna $(>1,000 \mathrm{~kg}$ ) by park managers into their reserves (i.e., the elephant [Loxodonta and Elaphus spp.] as a replacement for the mammoth, camel [Camelus spp.], Chacoan peccary [Catagonus wagneri], llama [Lama spp.], and lion [Panthera leo]). The purpose of restoring the structure of vertebrate communities is to reestablish the ecological drivers that originally influenced the habitat mosaic. It is, however, unlikely that elephants, camels, or other surrogates for the Pleistocene megafauna can be introduced to the North American prairie to restore habitat and animal diversity, or even that this course of action would be desirable.

The arrival of Euro-Americans on the Great Plains triggered a series of events that altered the character of the region and its biodiversity. Perhaps no set of events had a greater and more significant impact on the grasslands of the Great Plains than the United States Homestead Act of 1862 and the accompanying Canada Dominion Land Act of 1872 (Ostlie et al. 1997). Under this act in the United States, nearly 1.5 million people acquired over $800,000 \mathrm{~km}^{2}$ of land, primarily in the Great Plains region.

These Acts, coupled with land made available through an array of other federal acts and direct sale of lands to private landowners, resulted in a pronounced loss of native prairie, most often through conversion to agriculture. The impact was greatest in the tallgrass portion of the Plains, where soils were highly arable, but was signif- icant in all areas. Since the 1920s in the United States, changes in farming practices and federal agriculture policy have exacerbated the loss of native grasslands and soils (Barnes 1993).

Land-cover estimates based on recent thematic imagery place grassland systems loss across the Great Plains at $70 \%$, with tallgrass prairie regions retaining as little as $13 \%$ of the historic extent (Table 1). Mixed prairie $(29 \%)$ and shortgrass prairie $(52 \%)$ have retained
[P]rairie conservation requires: 1) new technology...to prioritize and set context to save prairie, 2) ecologically based initiatives to reverse significant losses in area and condition of native grasslands, 3 ) rethinking of standardized tools in the range management profession, and 4) a new natural resource agency.... larger proportions of the historic extent. Although simple estimates of remaining prairie can shed light on the status of biodiversity, they alone do not provide a clear and accurate prognosis for long-term persistence. Factors of patch size, condition, and landscape context play a major role in determining whether an ecological system or species will remain viable for an extended period of time.

Table 1. Summary by geographic unit (Bailey 1996) of estimated extent and decline in Great Plains prairie systems in North America by 2003. Historic extent of prairievegetatopm is based on Kuchler (1964).

\begin{tabular}{lrc}
\hline & $\begin{array}{c}\text { Remaining } \\
\text { extent }\left(\mathrm{km}^{2}\right)\end{array}$ & Percent of historic \\
\hline Biogeographic unit & 988,420 & 30.1 \\
\hline Great Plains bioregion & 82,680 & 13.4 \\
Tallgrass prairie province & 4,070 & 2.4 \\
Northern tallgrass prairie & 8,360 & 4.4 \\
Central tallgrass prairie & 26,480 & 37.6 \\
Osage plains/Flint hills prairie & 40,140 & 26.3 \\
Crosstimbers/Southern tallgrass & 3,630 & 9.5 \\
Gulf Coast prairies \& marshes & 608,010 & 29.1 \\
Mixed prairie province & 45,880 & 24.8 \\
Aspen parkland & 39,260 & 31.0 \\
Fescue-mixed prairie & 24,820 & 25.8 \\
Dakotas mixed prairie & 357,060 & 62.9 \\
Northern Great Plains steppe & 121,090 & 54.1 \\
Central mixed prairie & 19,900 & 21.0 \\
Edwards Plateau & 280,800 & 51.6 \\
Shortgrass prairie province & 140,530 & 64.3 \\
Central shortgrass prairie & 140,270 & 54.9 \\
Southern shortgrass prairie & 5,280 & 18.3 \\
Black Hills province & 11,650 & 7.9 \\
Tamaulipan thornscrub province & & \\
\hline
\end{tabular}




\section{Wildlife Society Bulletin 2004, 32(1):6-15}

\section{Ecological drivers}

Challenges other than loss and fragmentation of native grasslands exist in the conservation of Great Plains systems. An essential issue in conservation today is the role of ecological drivers (Knopf and Samson 1997).

Emphasis on landscape pattern alone and not the ecological drivers that provide an evolutionary and ecological context for species diversity neglects a vital component of species, community, and ecosystem conservation.

Ecological drivers on the Great Plains included drought at the broad scale and grazing and fire at the landscape and local scales (Fuhlendorf and Engle 2001). The Great Plains evolved in the rain shadow of the Rocky Mountains, where seasonal precipitation occurs mostly in spring and summer. From the Rocky Mountains east to the Mississippi River, amount of precipitation increases and frequency of drought decreases. Along the south-to-north gradient from central Texas to south-central Canada, the growing season becomes shorter, average temperature decreases, and a greater percentage of annual precipitation occurs as snow.

Broad-scale climate gradients significantly influence the evolutionary composition and distribution of prairie communities (Steinauer and Collins 1996). Average rates, however, are only partial drivers for prairie composition. Rather, the inherent unpredictability of precipitation among years is an important influence; severe droughts can cause massive local extinctions of annual forbs and grasses that have invaded stands of perennials, and recolonization of those sites is slow.

An ecosystem-specific description of the expected natural range (space and time) over which the primary ecological drivers operate is captured in the concept of Range of Natural Variation (RNV) (Aplet and Keeton 1999). The assumption is that when ecological drivers act with characteristic behavior, ecosystems exhibit characteristic composition and behavior.

The objective behind the application of RNV in prairie conservation is to restore and maintain the ecosystem conditions that sustained biological diversity prior to dramatic changes of the recent past. The bridge between the past and dramatic change on the northern Great Plains is the year 1770 (Higgens 1986). Any historic record (diary, photograph, and patent or land survey) after 1770 provides a description of a modified rather than a natural landscape, although records from 1770 to 1840 are accepted with caution. Among the possible reasons for this caution are 1) level of European use, particularly along waterways, 2) introduction of disease severely detrimental to indigenous nations, and 3) change in behavior of the dominant large herbivore, the bison (Bison bison). All of these are known to have changed the historic landscape (Nasatir 1952).
Analysis of RNV can help describe dynamic changes in vegetation and identify those vegetation types that were important historically but are less common or rare today (Haufler et al. 1996). For example, historically, the mixed prairie may have occurred as a relatively narrow transition zone between the tallgrass prairie and shortgrass prairie (Bessey 1893), extending south from eastern North Dakota into eastern Kansas (Blakeslee 1996).

Today, the western edge of the mixed prairie extends south from western North Dakota to far-west Kansas and Oklahoma.

Expression of ungulate herbivory and habitat selection at several scales impacts spatial and temporal patterns of animal and plant communities on the Great Plains (Milchunas et al. 1998). Herbivores and grasslands on the Great Plains have a long relationship extending over several million years. From an ecological perspective, significant recent changes to the Great Plains landscape resulted from reduction in the number and distribution of native herbivores and their replacement with domestic livestock (species adapted to the more mesic, wooded environments of Europe [Hartnett et al. 1997]) and the suppression of fire (Risser 1996).

Historically, bison moved nomadically in response to vegetation changes associated with rainfall and fire. The time lag for return movements provided deferment during the regrowth period, which, according to historic and archeological records, may have ranged from 1-8 years (Malainey and Sherriff 1996). This interval would have provided a natural rest interval and is consistent with spatial heterogeneity models that suggest stability in plant-herbivore interactions (Irby et al. 2002) and lead to a natural habitat mosaic of short, mid, and tall seral stages.

In the past $(<1840)$, fire may have been a yearly event in the tallgrass prairie (Edwin et al. 1966), occurred every 3-5 years in the mixed prairie (Umbanhowar 1996), and was an ecological driver on the shortgrass prairie (Brockway et al. 2002). Today, fire is rare on public lands managed by the United States Forest Service in the Northern Great Plains (Samson et al. 2003), affecting about $7.9 \mathrm{~km}^{2}$ per year (of $371.1 \mathrm{~km}^{2}$ ) in the tallgrass prairie, $33.4 \mathrm{~km}^{2}$ (of $17,663.4 \mathrm{~km}^{2}$ ) in the mixed prairie, and $14.2 \mathrm{~km}^{2}$ (of $2,675.8 \mathrm{~km}^{2}$ ) in the shortgrass prairie.

\section{Present}

\section{Minimum Dynamic Area (MDA)}

An area large enough to sustain an ecological system with all of its biodiversity has been termed MDA (Pickett and Thompson 1978). The MDA is the smallest area 
with a system of natural ecological drivers that support and sustain native biodiversity. In an MDA the size and number of vegetation patches remain relatively constant, though the location of patches in various stages of development changes over time. The advantage to setting reserve size (MDA) above that based on RNV is to permit natural drivers to continually refresh the natural amount of habitat and maintain approximate number and sizes of patches and their juxtaposition native to the landscape.

Analysis of MDAs can help identify areas important to the long-term persistence of biodiversity on the Great Plains (The Nature Conservancy 2000) and can help identify approaches that will sustain intermediate and other, smaller landscapes. Ostlie et al. (unpublished data) identified 47 MDAs (each $>1,000 \mathrm{~km}^{2}$ ) in the Great Plains that account for $28 \%$ of the bioregion area (Figure

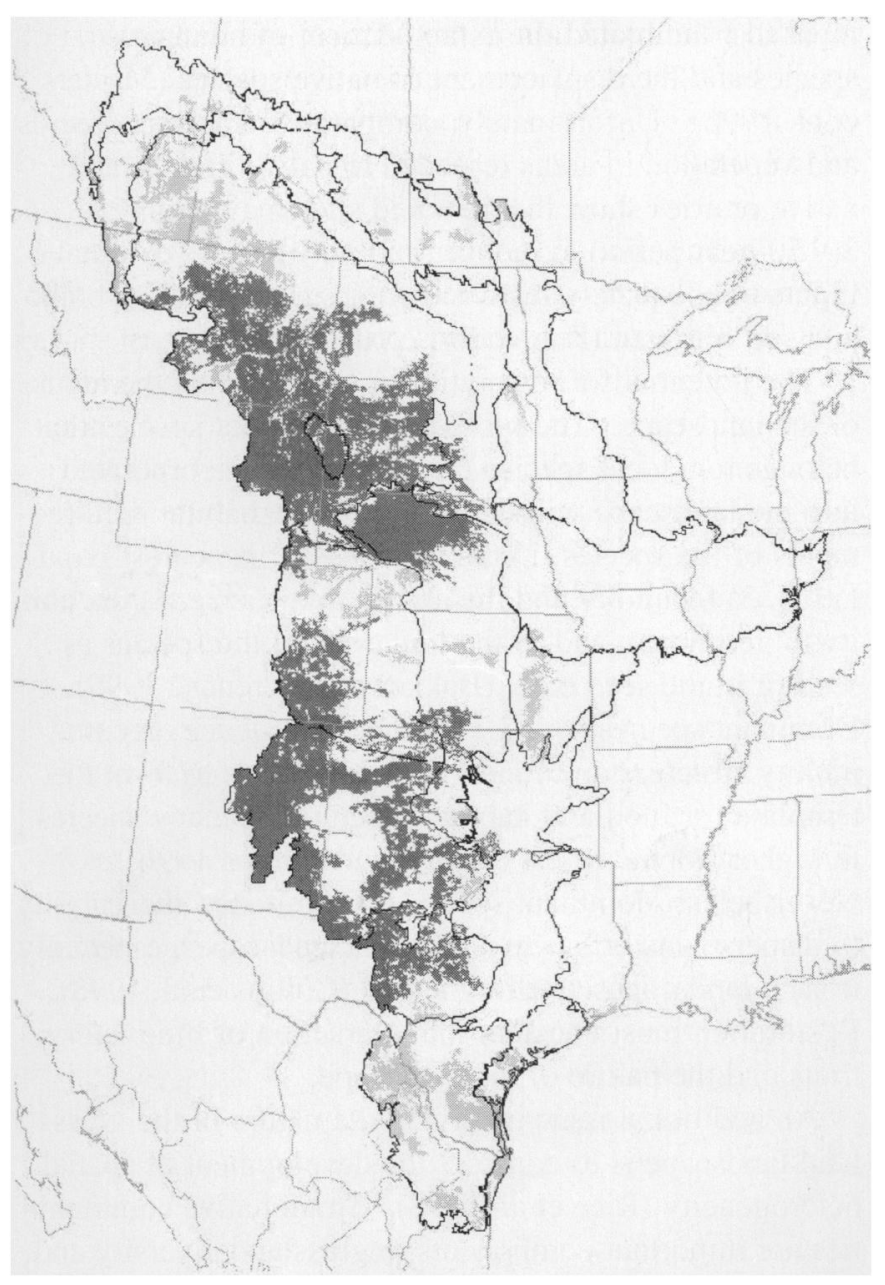

Figure 1. Major remaining areas of native prairie of North America by 2003: black lines delineate Kuchler (1964) biogeographic units, highly fragmented areas are in white, Minimum Dynamic Areas $(>100,000$ $\mathrm{km}^{2}$ ) are in light and dark gray. Dark gray areas further delineate relatively intact mixed prairie and shortgrass prairie landscapes that offer the best chance for action to conserve the full array of biodiversity.
1). They also capture $29 \%$ of the documented imperiledspecies occurrences in the Plains. These MDAs are principally in the western Great Plains, with $58 \%$ and $30 \%$ total area coverage in the mixed prairie and shortgrass prairie, respectively. Few landscapes in the tallgrass prairie and northern mixed prairie are $>1,000 \mathrm{~km}^{2}$. Large-scale restoration is required to restore these systems to an appropriate (MDA) scale.

Two prominent prairie landscapes occur in the northwest and southwest portions of the Great Plains and account for $70 \%$ of the total landscape. These 2 large and relatively intact mixed prairie and shortgrass prairie landscapes offer the best chance for comprehensive conservation action targeting the full array of biodiversity, including local- and regional-scale elements (e.g., large predators and ungulates native to the prairie) (Figure 1). Large size and existing linkages to other areas, most notably the adjacent Rocky Mountain region, bolster the value of these 2 landscapes for regional-scale species reintroduction.

\section{Future Conservation}

\section{Saving prairie}

Almost $93,000 \mathrm{~km}^{2}$ of United States grasslands were lost between 1982 and 1997, primarily to conversion to agriculture. This conversion occurred in both relatively dry grassland areas, such as Kansas, Colorado, and the western Dakotas, and in relatively wet grassland areas of the Midwest such as Wisconsin, Minnesota, and Illinois. Commodity programs in the western United States and elsewhere are tilting the balance in many locations from ranching and pasturing to the production of row crops. In general, the farm bill in the United States has promise for grassland conservation, with components such as the proposed Grassland Reserve Program that would provide incentives to landowners who voluntarily protect grassland systems.

In the early 1900s, the Canadian prairie region was known as the last best west, referring to the fact that this region contained the last free homesteads in North America (Radenbaugh and McDonald 2000). In common with prairie landscapes elsewhere, the extent of native prairie in Canada underwent drastic changes, and within many landscapes, human-related activities have dominant roles. In 2002 the Government of Canada announced a $\$ 190$ million investment to improve sustainability in agriculture, $\$ 100$ million to convert marginal cultivated lands to permanent cover (1.2 million ha), and to assist in identifying and protecting critical wildlife areas.

The Conservation Reserve Program (CRP) is thought by many to be essential to the conservation of grassland 
systems in the United States. However, many areas of historic prairie recently converted to agriculture and enrolled in CRP have been planted with expanses of native grasses. Fire, a natural ecological driver in grasslands, has a significant impact on farmland reseeded to artificial prairie. In the shortgrass prairie region, following wildfire, CRP lands experience extensive soil erosion compared to nearby native prairie (Figure 2). Without full ecological consideration of the living network in unbroken prairie soil, legislative approaches to grassland conservation must be cautious (Weaver 1968).

The vast majority of conservation theory began from simple concepts in which habitat is either saved or restored (Fahrig 1997). A case in point is The Nature Conservancy. The Nature Conservancy began conservation work in the Great Plains with the typical acquisition or gift acceptance of small tracts of remnant native prairie, most less than $1.5 \mathrm{~km}^{2}$ in size. The Conservancy today is undertaking science-based, region-wide conservation planning activities that recognize 1) the need for proactive conservation measures that complement the
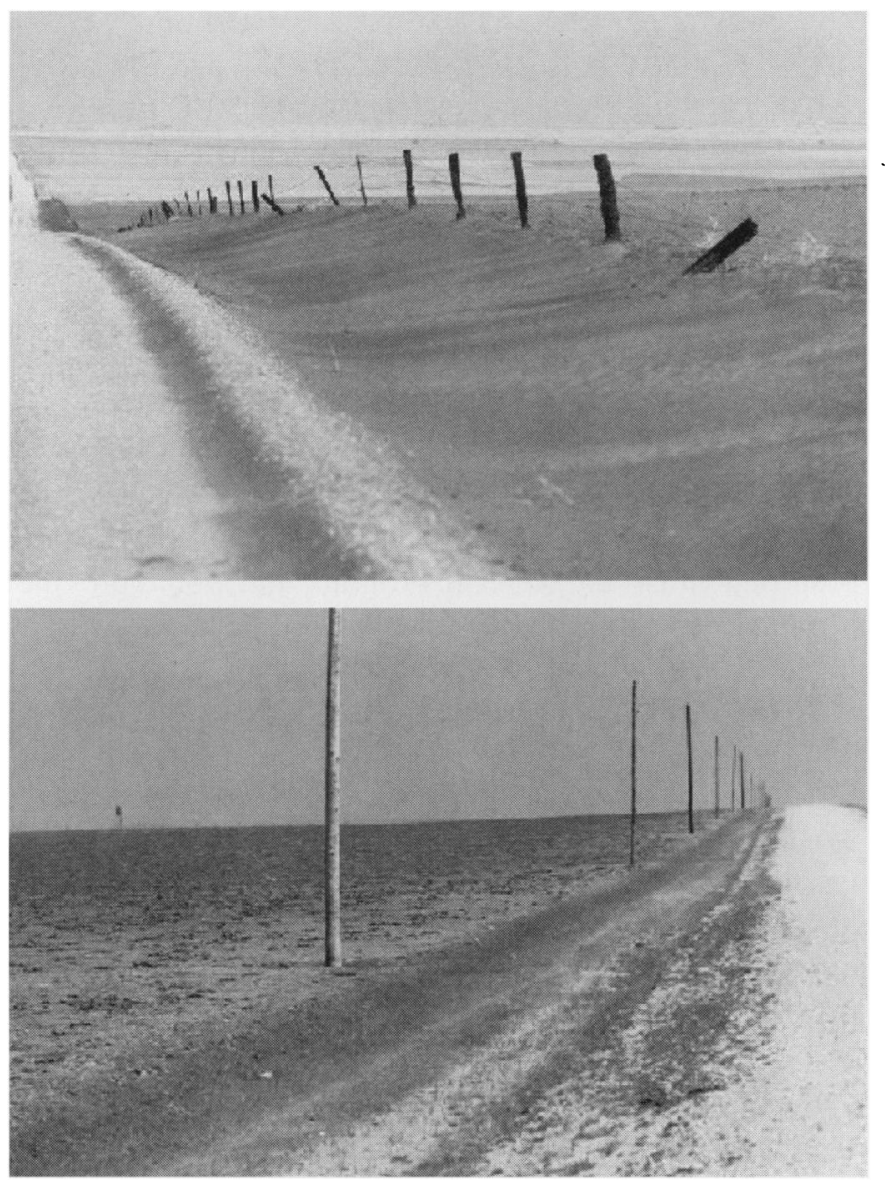

Figure 2. Post-burning, wind-induced soil erosion and loss on Conservation Reserve Program (above), and field versus native shortgrass prairie (below) at Keota, Colorado, June 2002. Photos by Fritz L. Knopf. reactive measures of most endangered-species programs, 2) that biodiversity occurs at (and must be conserved at) different spatial scales, and 3) the need to conserve the underlying ecological processes that support patterns of biodiversity. These efforts have identified areas that, if conserved, will address the needs of most elements of biodiversity within an ecoregion.

\section{Restoring prairie}

A recent panel of grassland ecologists, with particular expertise in grassland bird ecology, developed a number of consensus recommendations that provide guidance for prairie restoration (Searchinger 2002). In short, recommendations were to 1) emphasize diverse native grasses and forbs, 2) understand the nature of the landscape, and 3 ) be aware of the inherent role of grazing.

The productivity and diversity of Great Plains grasslands have been substantially reduced by past management that facilitated the establishment of nonnative species and the displacement of native species (Masters et al. 1996). Unfortunately, comparative analysis of soils and vegetation in areas reseeded to native grasses and native prairies show that restored sites may require a 30-50-year period to recover and may require external inputs to adequately restore organic matter, soil carbon, and soil nitrogen (Fuhlendorf et al. 2002).

The potential for restoration will depend on the nature of the landscape. The probability of a plant species that belongs to a local species pool becoming incorporated into the landscape will depend on 1) the habitat requirements of the species, 2) the distance to the nearest population, 3) fecundity and the ability to disperse, 4) the ability to germinate, and 5) the longevity of the species as seed or in the seed bank (Bakker and Berendse 1999). Dominant species have a significant influence on community structure and function in grasslands to form the template for food and habitat structure for many species in higher trophic levels (Vinton and Collins 1996).

Nevertheless, dominant species are limited in their ability to disperse and colonize additional landscapes, especially if such landscapes are fragmented (Collins et al. 1998). Restoration must consider the interaction of life-history traits and the nature of the landscape.

An additional issue involving the nature of the grassland landscape is to consider the development of spatial heterogeneity (Rice et al. 1998). Small native communities are important components to grassland diversity and may not reflect the dominant vegetation of a biome.

Restoration actions must match grasses or other species to the immediate surroundings rather than to the bioregion (Searchinger 2002). A working example is to create shortgrass prairie in a sand-sage prairie landscape. 
Despite the interest, the overall generality in the relationships of small-scale species diversity and the diversity-stability relationships at large scales, whether in ecology or in restoration, is poorly known (Seastedt et al. 1998).

Grazer population densities (stocking rates), type of grazer (native or domestic), and temporal pattern are primary determinants of grazing effects on grassland structure and function and success in restoration (Fuhlendorf et al. 2002). Both bison and prairie dogs (Cynomys ludovicianus) have multiple and drastic effects on grasslands, and both should be considered keystone herbivores (Fahnestock and Detling 2002). Historically, grazers, despite their relatively small biomass, had small (e.g., bison creating wallows important to many species) to large (e.g., distribution of primary productivity) impacts, suggesting both bottom-up and top-down influences on grassland systems (Steinauer and Collins 2001).

Understanding how both bottom-up and top-down forces influence factors controlling grassland and other communities is currently of wide ecological interest, yet this has not been a widespread focus in restoration or in management of lands in the CRP or similar legislative initiatives.

The importance of land-use history and its legacy is an integral part of conservation planning (Samson 1992).

Fire is important to the regulation of plant cover, diversity, biomass, and nutrient status in tallgrass prairie

(Johnson and Matchett 2001) and mixed prairie (Madden et al. 2002), with its role in the shortgrass prairie ecosystem yet to be fully understood (Glenn and Collins 1992). Little difference exists in the fire suppression across much of the native and reseeded grasslands on the Great Plains and that in the forests of the western United States, an issue in the political and conservation forefront. The encroachment of woody vegetation and nonnative species due to grazing by domestic livestock and suppression of fire has created an environmental challenge (Van Auken 2000) that is arguably equal to the ongoing debate in Congress and elsewhere relative to the health of western forests.

To date, not enough is known about restoration to predict how grasslands will respond over long time scales or to estimate a level of success (Collins et al. 1998).

Development of effective grassland restoration methods must include testing of hypotheses pertaining to the role of 1) resource heterogeneity (as influenced by ecological drivers), 2) life-history characteristics of native species as influenced by the nature of the landscape, 3 ) nutrient and soil conditions at the start of the restoration as influenced by cultivation and agriculture, and 4) how these factors, singly or in combination, influence species diversity in restored grassland vegetation.

\section{Range management}

The historic tallgrass prairie, or True Prairie, occurred along the eastern Great Plains, with a Prairie Peninsula radiating north and east into Indiana and Ohio during Pleistocene interglacials. Besides drought, wildfires perpetuated the true prairie by controlling brush encroachment on the northern, eastern, and southern perimeters.

The True Prairie has been geographically reduced more than $86 \%$ in the last 200 years, and the opportunity to recover or restore that ecosystem on any meaningful spatial scale has been lost. The debate for true prairie is not one of conservation. Rather, it involves the vision for re-creation. In True Prairie, remnant reserves and restorations are all that can be envisioned as long as the United States and Canada continue to subsidize the contemporary cereal-grain economy of that region.

Whereas the native megafauna of the Great Plains since the Pleistocene was characteristic of the shortgrass prairie and a much less-extensive mixed prairie, conservation vision to restore the Great Plains must focus on that region. It is in this region that the opportunity for conservation of a native landscape remains. Fortunately, most terrestrial endemic vertebrates evolved in these drier, westerly plains (Knopf 1996, Knopf and Samson 1997). Equally fortunate, the western Great Plains (unlike tallgrass prairie) contain opportunity in the form of lands held in public ownership.

Refocusing conservation and natural resource management of the shortgrass prairie and mixed prairie will take a concerted effort. The effort must include commitment beyond traditional thinking to begin working toward an ecological vision for the region. We offer that this transition challenges the profession of range management to rethink standardized tools and common practices used to pursue the underlying paradigm of stabilizing soils while maximizing forage production to provide a red-meat commodity. On the western prairies especially, the primary tool has been promotion of the allotment system for regulating grazing pressures on the landscape. What is the dated tool for defining grazing allotments? Fencing.

Fences are the problem in, not the solution to, conservation of historically grazed ecosystems. Fenced allotments enable management agencies to establish standardized guidelines (measures of residual forage) for removal of grazers from ecosystems. Rather than challenging the practice of fencing, the profession has committed itself to intensifying fencing on smaller spatial (and temporal) scales to achieve standard vegetation targets in the name of conservation. Fencing of locally important riparian areas, for example, is common, but it is both economically and biologically costly. Likewise, high-density fencing within the commodity-oriented system is moving to 


\section{Wildlife Society Bulletin 2004, 32(1):6-15}

the opposite end of the conservation continuum from a regional and ecosystem vision.

The range management profession must examine fencing approaches relative to perpetuating habitats of the native, endemic biota. Fencing cattle from riparian areas that historically were obliterated by bison promotes the growth of trees and biological ubiquity in native grass landscapes. The more intensive the fencing, the less probable the viability of native species such as prairie birds. Managing for standardized vegetative goals precludes endemic species at the ends of the ecological continuum of grazing activity. Managing in the middle across broad landscapes manages against species that require heavy grazing to create open areas and those that require lighter grazing that leaves more residual vegetation for the subsequent season's nesting cover (Knopf 1994). Managing for the middle across broad landscapes is managing to promote listings of species under the Endangered Species Act (1973).

Our ideas should not be viewed as threatening to the profession of rangeland management. Rather, we offer that the profession needs to think more in the perspective of longer temporal (historical) sustainability of native landscape. It's ironic that the Society for Range Management logo depicts a cowboy on horseback. While that lifestyle does survive in remnants of the Great Basin and Colorado Plateau, it has been managed off the landscape on the western Great Plains. A cowboy with many fences doesn't need a horse as much as a truck.

\section{Archaic agencies}

There is growing consensus that the current system of protecting the environment is inappropriate for meeting the challenges ahead (Samson and Knopf 2001). A new approach is required in which the environment is managed in a way similar to how any good business manages its valuable and productive assets (Costanza et al. 2000). This recognizes that the environment is of critical importance as a life-support system and shifts the burden-ofproof of conservation to those who potentially harm grasslands by their activities (e.g., overharvesting, habitat destruction, introduction of exotic species, and so on). Cases in point are the United States Department of Agriculture and the shelterbelt element of the Canadian Greencover Initiative to promote the planting of trees, which conflicts with carbon sequestration, a significant prairie ecosystem asset (Jackson et al. 2002).

A fundamental problem for natural resource conservation is that no effective organization exists at the appropriate spatial or temporal scales (Costanza et al. 2000). A striking example in the United States is the lack of congruence of federal agency administrative boundaries responsible for the conservation of threatened and endangered species and their distributions (Knopf 1992). The Great Plains is no exception to jurisdiction disintegration. This Great Plains resource is managed by at least 4 federal agencies, 7 administrative regions, 19 administrative areas or parks or supervisor units, and 44 districts. There are no consistent 1) criteria to identify species-at-risk, 2) approaches to species, community, or ecosystem viability, or 3 ) federal rules or models to develop and implement consistent and science-based conservation planning. Consolidation or realignment of federal agencies would reduce conflict in conservation of species-at-risk and facilitate the development of a step-down, cost-effective framework for their conservation (Samson and Knopf 2001).

Another issue is agency effectiveness (e.g., quick response to the public). Flexibility and the ability to change strategy if necessary are mandatory. The abilities to pull people together rather than subdividing tasks, and to promote sharing of new ideas and products are also necessary (Eisenshardt and Sull 2001). For instance, do our expectations in conserving the prairie dog or the lesser prairie-chicken (Tympanuchus pallidicinctus) need to be modulated in light of what we know about an adversarial state-federal agency system in which biologists match wits with one another?

Recommendations for agency separation, along with demands for better science in the legal process (Shaffer et al. 2002), chronically overestimate the power of agencies to be effective in political choices about science (Jasanoff 1998). The mechanics of conservation require an organizational design in natural resource conservation-one of effective agencies working with nongovernmental organizations and private landowners.

In the 1970s, when the context of environmental management was simpler, agencies could afford to have independent and complex conservation strategies. The environmental context is no longer simple. Today, lack of leadership and conflicting legal mandates for conservation have fostered a creeping paralysis in public land management in the United States (Samson and Knopf 2001). Understanding and opening dialogs in cooperative ventures and moving toward a shared conservation vision are the foundation of effective natural resource conservation. Both agency and ecosystem dysfunction can lead to loss of natural resources (Pressey 1998).

\section{Summary}

Theodore Roosevelt, in his most important conservation speech (i.e., Natural Resources-Their Wise Use or Their Waste), said, "The conservation of natural 


\section{Great Plains ecosystems - Samson et al.}

resources is only preliminary to the larger question of national efficiency" (Taylor 1911:1). Efficiency includes creative destruction (i.e., replacing existing technologies and processes with innovation and new organizations) (Shankin 2000). To increase efficiency, prairie conservation requires: 1) new technology (MDAs) to prioritize and set context to save prairie, 2) ecologically based initiatives to reverse significant losses in area and condition of native grasslands, 3 ) rethinking of standardized tools in the range management profession, and 4) a new natural resource agency, organized at the appropriate spatial scale and working effectively with nongovernmental organizations and private landowners.

The national strengths of Canada and the United States were built upon their collective wealth of natural resources. The evolution of natural resource management from sustainable harvest through multiple-use and then ecosystem-viability paradigms seemed to apply to all native biomes except the central grasslands. The tallgrass prairie was viewed as economically viable only when totally converted to an exotic ecosystem sustained by chemical additives. The mixed-prairie region followed this history but with additional engineering to supplement water resources for irrigation. Farther west, the shortgrass prairie suffered homogenization of the natural variability inherent in the world's native herbivore-driven landscape.

The Great Plains are America's 140-year Failed Frontier that has cost trillions of dollars in misguided farm programs and immeasurable heartbreak (Kristof 2002). We offer that North America's Great Plains have suffered from an abundance of fiscal greed and a shortfall of ecological common sense. The Great Plains are the birthplace of natural resource conservation in North America (Reiger 1986). The view from Mt. Rushmore is hardly the legacy Teddy Roosevelt imagined.

Acknowledgments. We thank N. Silvy and J. Wallace for their valuable editorial assistance, D. M. Engle and D. G. Milchunas, two anonymous reviewers for helpful suggestions, and The Wildlife Society for grassland and grassland wildlife conservation sessions at the annual meeting in Bismarck, North Dakota, USA.

\section{Literature cited}

APLeT, G. H., AND W. S. KeEton. 1999. Application of historic range of viability concepts to biodiversity conservation. Pages 71-86 in R. K. Baydack, H. Campa III, and J. B. Haufler, editors. Practical approaches to the conservation of biological diversity, 1999. Island Press, Washington D.C., and Covello, California, USA.

Bailey, R. G. 1996. Descriptions of the ecoregions of the United States. Miscellaneous Publication 1391. U.S. Department of Agriculture, Forest Service, Washington, D.C.
BAKKER, J. P., AND F. BERENDSE. 1999. Constraints in the restoration of ecological diversity in grassland and heathland communities. Trends in Ecology and Evolution 14:63-68.

BARNES, R. C. 1993. The U. C. C. insidious preference for agronomy over ecology in farm lending. University of Colorado Law Review 64: 457-512.

BESSEY, C. E. 1893. Seventh annual report of the botanist. Nebraska Board of Agriculture, Lincoln, USA.

BLAKESLEE, D. J. 1996. Persistence and change in the natural and cultural landscapes of the central plains. Transactions of the Kansas Academy of Sciences 99:86-94.

BROCKWAY, D., R. GATEWOOD, AND R. PARIS. 2002. Restoring fire as an ecological process in shortgrass prairie ecosystems: initial effects of prescribed burning during the dormant and growing seasons. Journal of Environmental Management 65:135-152.

Coluins, S. L.,A. K. KnaPP, D. C. HaRTnett, And J. M. Briggs. 1998. The dynamic tallgrass prairie: synthesis and research opportunities. Pages 301-316 in A. K. Knapp, J. M. Briggs, D. C. Hartnett, and S. L. Collins, editors. Grassland dynamics. Oxford University Press, New York, New York, USA.

Constanza, R., H. Daiy, C. Folke, P. Hawlen, C. S. Holling, A. J. MCMichael, D. PIMENTEl, AND D. RAPPORT. 2000. Managing our environmental portfolio. BioScience 50:149-150.

EDWIN, J., S. H. LONG, AND T. SAY. 1966. Stephen H. Long expedition to the Rocky Mountains, 1819-1820. University Microfilms, Ann Arbor, Michigan, USA.

EISENHARDT, K. M.,AND D. N. SuLl. 2001. Strategy as simple rules. Harvard Business Review 79:107-113.

FAHNESTOCK, J. I., AND J. I. Detung. 2002. Bison-prairie dog-plant interactions in North American mixed-grass prairie. Oecologia 132:86-95.

FAHRIG, L. 1997. Relative effects of habitat loss and fragmentation on population extinction. Journal of Wildlife Management 61:603-610.

FLANNERY,T. 2001. The eternal frontier: an ecological history of North America and its peoples. Atlantic Monthly Press, New York, New York, USA.

FUHLENDORF, S. D., AND D. M. ENGLE. 2001. Restoring heterogeneity on rangelands: ecosystem management based on evolutionary grazing patterns. BioScience 51:625-632.

Fuhlenidorf, S. D., H. Zhang, T. R. TunNell, D. M. ENGLE, ANd A. F. Cross. 2002. Effects of grazing on restoration of southern mixed prairie soils. Restoration Ecology 10:401-407.

GLENN, S. M., AND S. L. Coluins. 1992. Effects of scale and disturbance on rates of immigration and extinction. Oikos 63:273-280.

HARTNETT, D. C.,A.A. STUETER, AND K. R. Hickman. 1997. Comparative ecology of native and introduced ungulates. Pages 105-130 in F. L. Knopf and F. B. Samson, editors. Ecology and conservation of Great Plains Vertebrates. Ecological Studies 125, Springer-Verlag, New York, New York, USA.

HAUFLER, J. B., C.A. MEHL, AND G. J. RolofF. 1996. Using a coarse filter approach with species assessment for ecosystem management. Wildlife Society Bulletin 24:200-208.

Haufler, J. B., R. K. BaybaCK, H. Campa III, B. J. Kernohan, C. Miller, L. J. O'NeIL, AND L. WATTS. 2002. Performance measures for ecosystem management and ecological sustainability. Technical Review 02-1. The Wildlife Society, Bethesda, Maryland, USA.

HigGens, K. F. 1986. Interpretation and compendium of historical fire accounts in the northern Great Plains. United States Department of Interior Fish and Wildlife Service Resource Publication 161, Washington, D.C., USA

IrBY, L. R., J. E. NoRLAND, J.A. WeStLAND, AND M.A. SUlLIVAN. 2002. Evaluation of a forage allocation model for Theodore Roosevelt National Park. Journal of Environmental Management 64: 153-169.

JaCKSON, R. B., J. L. BanNeR, E. G. JobBagy, W.T. PoCKaman, AND D. H. Walls. 2002. Ecosystem carbon loss with woody plant invasion of grasslands. Nature 418:623-626. 


\section{Wildlife Society Bulletin 2004, 32(1):6-15}

JASANOFF, S. 1995. Science at the bar. Law, science, and technology in America. Harvard University Press, Cambridge, Massachusetts, USA. Johnson, L. C., AND J. R. MATchetT. 2001. Fire and grazing regulated belowground processes in tallgrass prairie. Ecology 82:3377-3389.

KNOPF, F. L. 1992. Faunal mixing, fauna integrity, and the biopolitical template for diversity conservation. Transactions of the North American Wildlife and Natural Resources Conference 57:30-342.

KNOPF, F. L. 1994. Avian assemblages on altered grasslands. Studies in Avian Biology 15:247-257.

KNOPF, F. L. 1996. Prairie legacies-birds. Pages 135-148 in F. B. Samson and F. L. Knopf, editors. Preserving North America's most endangered ecosystem. Island Press, Covello, California and Washington, D. C., USA

KNOPF, F. L., AND F. B. SAMSON. 1997. Ecology and conservation of Great Plains Vertebrates. Ecological Studies 125. Springer-Verlag, New York, New York, USA.

Kristof, N. D. 2002. America's Failed Frontier. New York Times. 3 September 2002; section A: 19

KUCHLER, A.W. 1964. Potential natural vegetation of the conterminous United States. Special Publication 36. New York:American Geographical Society, New York, New York, USA

Madden, E. M.,A. J. Hansen, AND R. K. MurPhy. 1999. Influence of prescribed fire history on habitat and abundance of passerine birds in northern mixed-grass prairie. Canadian Field-Naturalist 4:627-640.

Malainey, M. E., AND B. L. SherRifF. 1996. Adjusting our perceptions: historical and archaeological evidence of winter on the plains of Western Canada. Plains Anthropologist 41:333-357.

Masters, R.A., S. J. Nissen, R. E. Gaussoin, D. D. Beran, AND R. N. Stougard. 2002. Imidazoline herbicides improve restoration of Great Plains grasslands. Weed Technology 10:392-403.

Milchunas, D. G., W. K. LaUENROTH, AND I. C. BuRKE. 1998. Livestock grazing: animal and plant biodiversity of shortgrass steppe and the relationship to ecosystem function. Oikos 83:65-74.

NaSATIR,A. P. 1952. Before Lewis and Clark. Volumes 1 \& 2. St. Louis Historical Documents Foundation, St. Louis, Missouri, USA.

OstLie, W. R., R. E. SCHNEIDER, J. M.AldRich, T. M. FAuST, R. L. B. MCKim, AND S. J. ChAPLIN. 1997. The status of biodiversity in the Great Plains. The Nature Conservancy, Minneapolis, Minnesota, USA.

Pickett, S.T.A., AND J. N.Thompson. 1978. Patch dynamics and the design of reserves. Biological Conservation 13:27-37.

Pressey, R. L. 1998. Algorithms, politics and timber: an example of the role of science in a public, political negotiation process over new conservation areas in production forests. Pages 73-87 in R. Wills and R. Hobbs, editors. Ecology for everyone: communicating ecology to scientists, the public and the politicians. Surrey Beatty and Sons, Sydney, Australia.

RADENBAUGH,T.A., AND P. C. Douaud. 2000. Introduction: changing landscapes of the Northern Great Plains. Pages 1-8 in T.A. Radenbaugh and P. Douaud, editors. Changing prairie landscapes. Canadian Plains Research Center, University of Regina, Saskatoon, Saskatchewan, Canada

RAVEN, P.H. 1990. The politics of preserving diversity. Bioscience 40: 769-774.

REIGER, J. F. 1986. American sportsmen and the origins of conservation. University of Oklahoma Press, Norman, USA.

Rice, C. W., T. C. Todd, J. M. Blair, T. R. Seastedt, R. A. Ramundo, and G.W.T. WILSON. 1998. Belowground biology and processes. Pages 244-264 in A. K. Knapp, J. M. Briggs, D. C. Hartnett, and S. L. Collins, editors. Grassland dynamics. Oxford University Press, New York, New York, USA

Rickletts, T. H., E. Dinerstein, D. M. Olsen, C. J. Loucks, W. Eichbaum, D. DellaSala, K. Kavanagh, P. Hedao, P.T. Hurley, K. M. Carney, R. Abell, AND S. WALTERS. 1999. Terrestrial ecoregions of North America. Island Press, Washington D.C., and Covello, California, USA.

RISSER, P. 1996. A new framework for prairie conservation. Pages
261-274 in F. B. Samson and F. L. Knopf, editors. Prairie conservation. Preserving North America's most endangered ecosystem. Island Press, Washington D. C., and Covello, California, USA.

SAMSON, F. B. 1992. Conserving biodiversity in sustainable ecosystems. Transactions of the North American Wildlife and Natural Resource Conference 57:308-320.

SAMSON, F. B.,AND F. L. KNopf. 1994. Prairie conservation in North America. BioScience 44:418-421.

Samson, F. B., AND F. L. KNopf. 1996. Prairie conservation. Preserving North America's most endangered ecosystem. Island Press, Washington D.C., and Covello, California, USA.

SAMSON, F. B., AND F. L. KNOPF. 2001. Archaic agencies, muddled missions, and conservation in the 21 st century. BioScience $51: 869-873$.

Samson, F. B., F. L. KNOPF, C. L. MCCARTHy, W. R. Hostile, S. Larson, G. E. Plumb, B. R. Noon, D. N. SVIngen, G. L. SCHENBeCK, S. M. RineHART, ANd T. W. BYER. 2003. Planning for population viability on Northern Great Plains grasslands. Wildlife Society Bulletin 31:986-999.

SEARCHINGER,T. D. 2002. Letter to The Honorable Tom Harkin and The Honorable Richard Luger. 2002, January 28. On file, The Environmental Defense Fund, Washington, D.C, USA.

SeAstedt, T. R., B. P. Hayden, C. E. Owensby, and A. K. KnapP. 1998. Climate change, elevated $\mathrm{CO}_{2}$, and predictive modeling: past and future climate change scenarios for the tallgrass prairie. Pages 283-300 in A. K. Knapp, J. M. Briggs, D. C. Hartnett, and S. L. Collins, editors. Grassland dynamics. Oxford University Press, New York, New York, USA.

Shaffer, M. L., L. H. WATChMAN, W. J. SNAPE III, AND I. K. LATChIS. 2002. Population viability analysis and conservation. Pages $123-145$ in S. R. Beissenger and D. R. McCullough, editors. Population viability analysis, University of Chicago Press, Chicago, Illinois, USA.

SHANKIN, W. L. 2000. Creatively managing for creative destruction. Business Horizons 43: 29-36

Steinauer, E. M.,And S. L. Coluins. 1996. Prairie ecology-the tallgrass prairie. Pages 39-52 in F. B. Samson and F. L. Knopf, editors. Prairie conservation. Preserving North America's most endangered ecosystem. Island Press, Washington D.C., and Covello, California, USA.

Steinauer, E. M., AND S. L. Collins. 2001. Feedback loops in ecological hierarchies following urine deposition in tallgrass prairie. Ecology 82:1319-1329.

TAYLOR, F.W. 1911. The principles of scientific management. Harper \& brothers, New York, New York, USA. Available online at http:// www.fordham.edu.halsal/mod/1911 (accessed 14 September 2003)

The Nature Conservancy. 2000. Ecoregional planning in the Osage Plains/Flint Hills Prairie. The Nature Conservancy, Midwestern Resource Office, Minneapolis, Minnesota, USA

UMBANHOWAR, C. E. 1996. Recent fire history of the northern Great Plains. American Midland Naturalist 135:115-121.

VAN AUKEN, O.W. 2000. Shrub invasions of North American semiarid grasslands. Annual Review of Ecology and Systematics 31:197-215.

VINTON, M.A., AND S. L. ColLINS. 1996. Landscape heterogeneity gradients and habitat structure in native grasslands of the central Great Plains. Pages 3-19 in F. L. Knopf and F. B. Samson, editors. Ecology and conservation of Great Plains vertebrates. Springer Verlag, New York, New York, USA.

WEAVER, J. E. 1968. Prairie plants and their environment. University of Nebraska Press, Lincoln, USA.

Fred B. Samson (top left) is a regional wildlife ecologist for the United States Forest Service in Missoula, Montana. He received his B.A. in business and M.S. in zoology form Indiana University and a Ph.D. in ecology from Utah State University. Fred has worked for the United States Fish and Wildlife Service and for the United States Forest Service research and management, and taught at Pennsylvania State University, State College; the University of Missouri-Columbia; and Colorado State University, Fort Collins. His primary conservation activities are large-scale planning and applied biodiversity conserva- 
tion, with a particular interest in the Great Plains grasslands. Fritz $\boldsymbol{L}$. Knopf (bottom left) received his B.A. in biology form Hiram College and M.S. and Ph.D. in wildlife ecology from Utah State University. $\mathrm{He}$ is currently a senior scientist with the United State Geological Survey's Biological Resources Division, Fort Collins, Colorado; has served as project leader and branch chief of vertebrate ecology for the National Biological Survey; and has taught at Oklahoma State

University. Fritz's primary research interests are in the conservation of Great Plains grasslands, declining wildlife that depend on prairie, and rare grassland species including the mountain plover. Wayne $\boldsymbol{R}$.

Ostlie's (top right) current position is senior management, Ecoregional
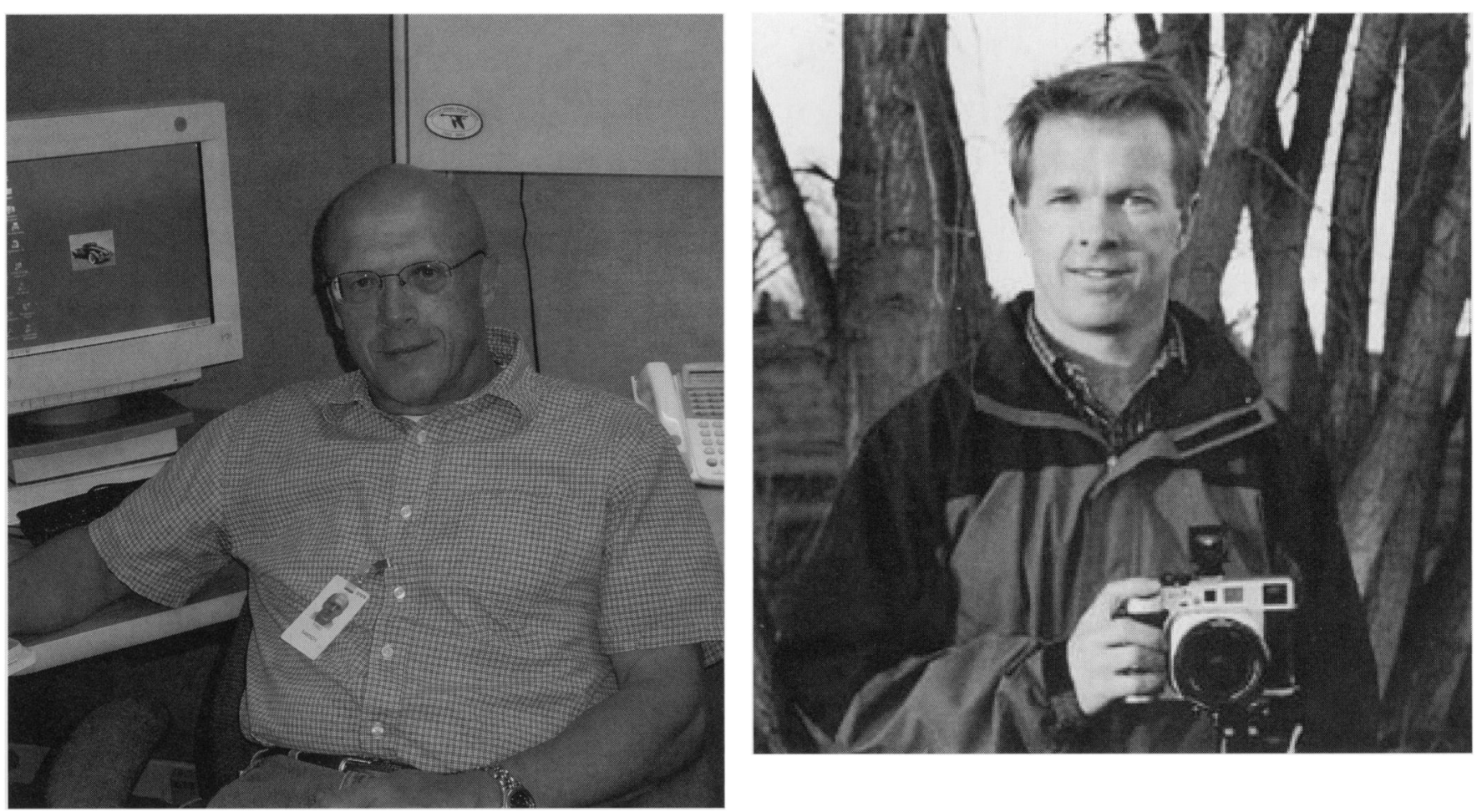

Assessment Learning Center, The Nature Conservancy, in Washington, D.C. Since 1987 Wayne has held a number of positions with the Conservancy including director of science for the Great Plains Program and director of science and stewardship with the Conservancy Field Office. He received a B.A. in biology from Luther College and an M.A. in biology from the University of Kansas. His primary interest is to deliver training, peer review, tools, and methods to ecoregional practitioners worldwide.

Special section associate editor: Silvy

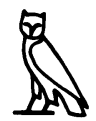

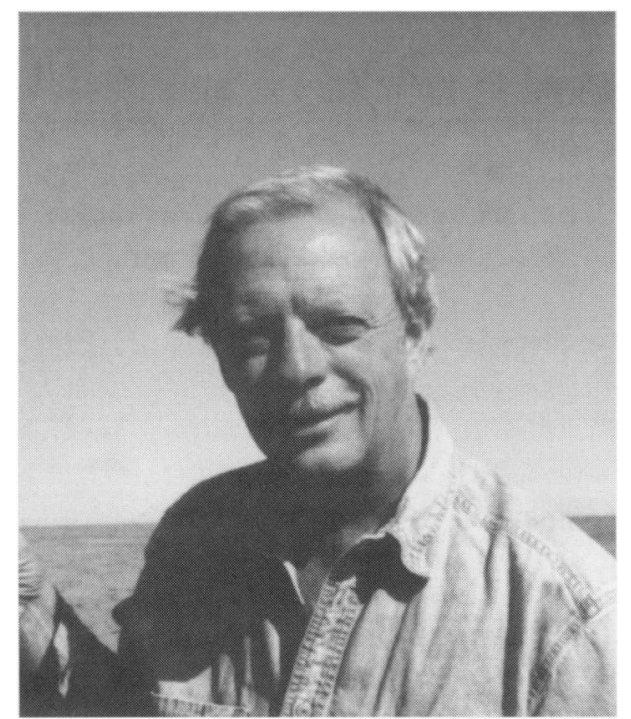

